\title{
Effects of insulin-like growth factor-I treatment on the endocrine pancreas of hypophysectomized rats: comparison with growth hormone replacement
}

\author{
T Jevdjovic, C Maake, E Eppler, E Zoidis ${ }^{1}$, M Reinecke and J Zapf ${ }^{1}$ \\ Division of Neuroendocrinology, Institute of Anatomy, University of Zürich, Winterthurerstr. 190, CH-8057 Zürich, ${ }^{1}$ Division of Endocrinology and \\ Diabetes, Department of Internal Medicine, University Hospital of Zürich, Rämistr. 100, CH-8091 Zürich, Switzerland
}

(Correspondence should be addressed to J Zapf; Email: juergen.zapf@usz.ch)

\begin{abstract}
Background: In GH-deficient humans, GH and IGF-I treatment cause opposite effects on serum insulin concentrations and insulin sensitivity. This finding contrasts with the somatomedin hypothesis that IGF-I mediates GH action, as postulated for skeletal growth, and raises the question whether GHinduced IGF-I acts on the endocrine pancreas in the same way as administered IGF-I.

Objective: To compare the effects of the two hormones on the endocrine pancreas of hypophysectomized rats.

Methods: Animals were infused for 2 days, via miniosmotic pumps, with IGF-I ( $300 \mu \mathrm{g} / \mathrm{day})$, GH (200 mU/day) or vehicle. We measured (i) glucose, IGF-I, insulin, C-peptide and glucagon in serum and (ii) IGF-I, insulin and glucagon mRNAs and peptides in the pancreas by radioimmunoassay, immunohistochemistry and northern analysis.

Results: Both GH and IGF-I treatment increased serum and pancreatic IGF-I but, unlike GH, IGF-I treatment strongly reduced serum insulin and C-peptide (and, to a lesser extent, serum glucagon). Nevertheless, the animals did not become hyperglycaemic. GH, but not IGF-I, increased pancreatic insulin and glucagon content, as also indicated by immunohistochemistry, and increased IGF-I mRNA. Neither GH nor IGF-I caused significant changes in insulin and glucagon mRNA.

Conclusions: The decrease in serum insulin and C-peptide by IGF-I treatment without significant changes in insulin gene expression and pancreatic insulin content suggests inhibition of insulin secretion. Within this setting, the absence of hyperglycaemia points to enhanced insulin sensitivity, although an insulin-like action of infused IGF-I may have partially compensated for the decreased insulin concentrations. GH-induced circulating or pancreatic IGF-I, or both, does not mimic the pancreatic effects of infused IGF-I in the absence of GH, suggesting that GH may counteract the action of GH-induced IGF-I on the endocrine pancreas.
\end{abstract}

European Journal of Endocrinology 151 223-231

\section{Introduction}

It is generally accepted that insulin-like growth factor (IGF)-I mediates the effects of growth hormone (GH) on tissues concerned with growth. Most of the IGF-I in the circulation is synthesized and released by the liver under the influence of $\mathrm{GH}$ but, in addition, $\mathrm{GH}$ also stimulates the production of IGF-I in extrahepatic tissues, thereby increasing its local concentration $(1,2)$. The relative contributions of circulating and locally produced IGF-I in mediating the effects of GH remain a matter of debate $(3,4)$.

Another question is whether or not other effects of $\mathrm{GH}$, such as those on the endocrine pancreas and on glucose homeostasis, are also mediated by the action of circulating or locally produced IGF-I, or whether these effects are direct and, thus, independent of IGF-I. The latter view is supported by the findings of a study in GH-deficient humans treated for several days with IGF-I, GH or a combination of both hormones (5), which showed that IGF-I suppressed serum insulin and C-peptide concentrations and increased insulin sensitivity, whereas GH increased serum insulin and C-peptide concentrations and decreased insulin sensitivity. IGF-I in conjunction with GH treatment counteracted these effects of $\mathrm{GH}$.

In contrast, studies in mice in which the IGF-I gene in the liver had been deleted and in which the serum IGF-I concentrations were decreased by more than $75 \%$ of normal, have pointed to a role of circulating IGF-I in the regulation of insulin secretion, insulin sensitivity and glucose homeostasis $(6,7)$. However, the changes observed in these animals, such as hyperinsulinaemia, islet cell hyperplasia and insulin insensitivity, may well have been caused by the more than sixfold increase in the serum concentrations of $\mathrm{GH}$ (6) as a 
result of negative feedback regulation of pituitary GH secretion by low circulating IGF-I. As the expression of IGF-I mRNA in extrahepatic tissues was apparently normal (4), and not increased as one would have expected in the presence of the increased GH concentrations, one might argue that the above changes in this animal model were not mediated via IGF-I, but rather were the result of direct $\mathrm{GH}$ action. This is also indicated by the finding that administration of a $\mathrm{GH}-$ releasing hormone antagonist that reduced serum $\mathrm{GH}$ concentrations improved insulin sensitivity (6). Nevertheless, a direct role of IGF-I could not be excluded, because IGF-I treatment not only normalized serum $\mathrm{GH}$ and insulin concentrations, but also completely restored insulin sensitivity (6).

In order to reassess this issue independently of endogenous GH, we infused hypophysectomized (hypox) rats with either GH or IGF-I for 2 days via miniosmotic pumps, and compared the effects of these two hormones on the expression of IGF-I, insulin and glucagon mRNA and peptide in the pancreas, and on the serum concentrations of glucose, IGF-I, insulin, C-peptide and glucagon.

\section{Materials and methods}

\section{Animals}

All animal experiments were approved by the Institutional Animal Welfare Committee. Hypox male Wistar rats (body weight $150-160 \mathrm{~g}$, age 7 weeks) were obtained from Charles River Laboratories (Charles River, Iffa Credo, France). The rats were kept at $25^{\circ} \mathrm{C}$ on a cycle of $12 \mathrm{~h}$ light $/ 12 \mathrm{~h}$ darkness and had free access to food and drinking water. Animals that gained less than $2 \mathrm{~g}$ during 1 week before the experiment were selected for infusion.

\section{Infusion procedure}

Alzet miniosmotic pumps (model 2001, Alza, Palo Alto, CA, USA) were filled with vehicle $(0.1 \mathrm{~mol} / \mathrm{l}$ acetic acid), recombinant human (rh) IGF-I (provided by Dr K Müller, Novartis Pharma AG, Basel, Switzerland) dissolved in vehicle, or rhGH (Novo Nordisk, Gentofte, Denmark) dissolved in $\mathrm{H}_{2} \mathrm{O}$ /benzyl alcohol (as provided by the supplier). The miniosmotic pumps were implanted subcutaneously in the abdomen with the animal under ether anaesthesia. Animals were infused for 2 days with vehicle $(n=6)$, rhIGF-I $(n=6$, $300 \mu \mathrm{g} / \mathrm{rat}$ per day), or rhGH $(n=6,200 \mathrm{mU}$ $(67 \mu \mathrm{g}) /$ rat per day). Rats were weighed at $0900 \mathrm{~h}$ before and after the infusion.

After 2 days of infusion, the rats were anaesthetized with pentobarbitone (Abbott Laboratories SA, Baar, Switzerland) and bled by aortic puncture. Blood samples were collected on ice. After clotting, they were centrifuged for $30 \mathrm{~min}$ at $3000 \mathrm{~g}$ at $4{ }^{\circ} \mathrm{C}$. Serum was pipetted off and stored at $-20{ }^{\circ} \mathrm{C}$. The pancreas was excised, weighed and divided into three parts for RNA extraction, peptide extraction and fixation for immunohistochemistry. Total RNA was extracted immediately after removal of the tissue using the extraction medium provided with the RNA extraction kit (NucleoSpin RNA II, Machery-Nagel, Düren, Germany). Tissue for protein extraction was stored at $-70{ }^{\circ} \mathrm{C}$ until extraction was performed (see below).

\section{Analytical procedures}

Serum glucose was determined with a Beckman glucose analyser (Beckman Coulter, Fullerton, CA, USA).

\section{Extraction of pancreatic tissues}

Fifty milligrams of pancreatic tissue were homogenized using a Polytron homogenizer (Kinematica, Luzern, Switzerland) in $1 \mathrm{ml}$ ice-cold acidic alcohol $(0.18 \mathrm{~mol} / \mathrm{l} \mathrm{HCl}-70 \%$ ethyl alcohol), incubated over night at $+4{ }^{\circ} \mathrm{C}$ and centrifuged at $16000 \boldsymbol{g}$ for $5 \mathrm{~min}$. The supernatants were used for the determination of insulin, glucagon and IGF-I content using specific RIAs.

\section{Radioimmunoassays}

Pancreatic and serum insulin concentrations were determined with a rat RIA kit (Linco Research, Inc., St Charles, MO, USA). Serum C-peptide and serum and pancreatic glucagon concentrations were measured with rat C-peptide and rat glucagon RIA kits, respectively (Linco Research, Inc.). All serum concentrations were determined in undiluted samples. For the determination of pancreatic insulin and glucagon concentrations, extracts were diluted 1:2000 to 1:4000 in the assay buffer provided. Serum and tissue concentrations of administered rhIGF-I and of endogenous rat IGF-I were determined by two different RIAs with two different antisera after SepPak C18 chromatography (Waters Corp., Milford, MA, USA) of the samples, as described in detail previously $(8,9)$. For the determination of IGF-I in pancreatic extracts, $0.5 \mathrm{ml}$ extract were lyophilized, dissolved in $0.25 \mathrm{ml}$ PBS containing $0.2 \%$ human serum albumin (HSA), centrifuged and run over SepPak C18 cartridges according to the procedure supplied by Immunonuclear (Stillwater, MN, USA). After reconstitution with $0.6 \mathrm{ml}$ PBS-0.2\% HSA, samples were assayed at three different dilutions (undiluted, 1:2 and 1:4) in the rhIGF-I or in the rat IGF-I RIA $(8,9)$ using rhIGF-I or recombinant rat IGF-I (GroPep, Adelaide, Australia) respectively as standards.

In our human IGF-I RIA, rat IGF-I does not crossreact; the values obtained in this RIA therefore reflect only the concentrations of the infused rhIGF-I. In the rat RIA, human IGF-I crossreacts four to five times better than rat IGF-I, so that endogenous rat IGF-I 
cannot be determined in rhIGF-I-infused animals; total IGF-I concentrations in these animals can be estimated by adding mean endogenous IGF-I concentrations of hypox controls. In animals infused with $\mathrm{GH}$ and in the control animals (absence of rhIGF-I), the RIA values represent endogenous rat IGF-I concentrations.

Serum concentrations of infused rhGH were determined with a commercially available IRMA kit (Schering AG, Basel, Switzerland).

\section{Determination of blood volume in pancreatic tissue}

The amount of blood in pancreas was determined according to the technique of Hohorst et al. (10). This method is based on the assumption that the proportion of oxyhaemoglobin $\left(\mathrm{HbO}_{2}\right)$ is approximately the same in circulating blood and in tissue capillaries. Briefly, $0.1 \mathrm{ml}$ heparinized rat blood was diluted in $25 \mathrm{ml}$ water and haemolysed for $10 \mathrm{~min}$ on ice. Pancreatic tissue was homogenized in water $(5 \mathrm{ml} / \mathrm{g})$. The homogenates were centrifuged at $16000 \mathrm{~g}$ for $10 \mathrm{~min}$ at $4{ }^{\circ} \mathrm{C}$. The supernatants were transferred to fresh tubes and the pellets resuspended in water $(2 \mathrm{ml} / \mathrm{g})$ and recentrifuged. The supernatants were pooled and kept on ice. After vigorous shaking for $1 \mathrm{~min}$, the absorption spectra of blood and pancreas homogenate at several dilutions were recorded between 500 and $650 \mathrm{~nm}$. The absorbance differences $\left(\Delta \mathrm{A}_{\mathrm{HbO}_{2}}\right.$ for tissue extracts and $\Delta \mathrm{A}_{\mathrm{HbO}_{2}}^{\prime}$ for blood samples) were determined by drawing a straight line between the two extinction maxima at 540 and $578 \mathrm{~nm}$ and a parallel line through the extinction minimum at $560 \mathrm{~nm}$ of the $\mathrm{HbO}_{2}$ spectra obtained for the tissue extracts and the blood dilutions, respectively. The fraction $X$ of the blood in the tissue was calculated as follows:

$$
X=\left(\Delta A_{\mathrm{HbO}_{2}} \times F_{1} \times d_{1}\right) /\left(\Delta A_{\mathrm{HbO}_{2}}^{\prime} \times F_{2} \times d_{2}\right) \times 100(\%)
$$

where $F_{1}$ and $F_{2}$ are the dilution factors and $d_{1}$ and $d_{2}$ the respective light paths of the cuvettes.

\section{Immunohistochemical procedure}

Pancreas specimens were fixed in Bouin's solution without acetic acid for $4 \mathrm{~h}$, embedded in paraffin and processed for double immunofluorescence as described previously (11). Briefly, $4 \mu \mathrm{m}$ pancreas sections were cut, deparaffinized and rehydrated. Non-specific binding was reduced by treatment of the sections with PBS containing 2\% BSA for $30 \mathrm{~min}$ at room temperature and processed for double immunofluorescence. The sections were incubated with a rabbit antiserum against porcine glucagon (code: A565, 1:2000; Dako, Carpinteria, CA, USA), or a rabbit antiserum against human IGF-I (code: $117,1: 600$ (11)) for $18 \mathrm{~h}$ at $4{ }^{\circ} \mathrm{C}$. After three washings with $\mathrm{PBS}-2 \%$ BSA, the rabbit antisera were visualized by incubation for $2 \mathrm{~h}$ at room temperature with fluorescein-isothiocyanate-labelled goat anti-rabbit IgG (1:100; Dako). For the detection of insulin, sections were incubated for $18 \mathrm{~h}$ at $4{ }^{\circ} \mathrm{C}$ with a guineapig antiserum against porcine insulin (code: A564, 1:18000; Dako), washed three-times with PBS-2\% BSA and treated with biotinylated goat anti-guineapig IgG (1:100; Bioscience, Emmenbrücke, Switzerland) and streptavidin Texas red (1:100; Amersham, Dübendorf, Switzerland) for $30 \mathrm{~min}$ at room temperature. For control incubations, the primary antisera were replaced by non-immune sera or preabsorbed with the respective antigens $(0.4-40 \mu \mathrm{g}$ peptide/ml diluted antiserum). The sections were examined and photographed with a confocal laser-scanning microscope (Leica, Heidelberg, Germany).

\section{Preparation of cDNA probes}

Total RNA from rat pancreas (for generation of the glucagon cDNA probe) and liver (for generation of the IGFI probe) was reverse transcribed by M-MLLV reverse transcriptase (Promega, Madison, WI, USA) in the presence of oligo $(\mathrm{dT})$ primer and in $1 \times$ reaction buffer $[5 \times 250 \mathrm{mmol} / \mathrm{l}$ Tris-HCl $(\mathrm{pH} 8.3), 375 \mathrm{mmol} / \mathrm{l} \mathrm{KCl}$, $15 \mathrm{mmol} / \mathrm{l} \mathrm{MgCl}_{2}$ and $50 \mathrm{mmol} / \mathrm{l}$ dithiothreitol], according to the manufacturer's instructions. The cDNAs were subjected to PCR. For IGF-I, the senseprimer 5'-ACATCATGTCGTCTTCACATC-3' and the antisense-primer 5'-GGTCTTGTTTCCTGCACTTC-3', spanning the nucleotide sequence 38-395 (GenBank Accession no. D00698), and for glucagon the sense primer 5'-AACGAAGACAAACGCCATTC-3' and the antisense primer 5'-GCCCAAGTTCCTCAGCTATG-3', corresponding to the nucleotide sequence 138-428 (GenBank Accession no. NM 012707) were used. The rat insulin cDNA probe (500 bp fragment) was kindly provided by Dr J H Nielsen (Hagedorn Research Institute, Gentofte, Denmark). The yeast $18 \mathrm{~S}$ ribosomal cDNA probe was a gift from Dr M Kalousek (University Hospital Zürich).

All PCRs were performed in a GeneAmp PCR System (9600; Perkin Elmer Corp., Norwalk, CT, USA) cycler in $1.5 \mathrm{mmol} / \mathrm{l} \mathrm{MgCl}_{2}, 0.2 \mu \mathrm{mol} / \mathrm{l}$ each primer, $200 \mu \mathrm{mol} / \mathrm{l}$ each dNTP, and $1 \mathrm{U}$ Taq polymerase (Qbiogene Inc., Basel, Switzerland) as recommended by the supplier. The amplification conditions were optimized to achieve linear PCR signals. For glucagon they were: one cycle of $1 \mathrm{~min}$ at $95^{\circ} \mathrm{C}, 45 \mathrm{~s}$ at $59^{\circ} \mathrm{C}, 1 \mathrm{~min}$ at $72^{\circ} \mathrm{C} ; 33$ cycles of $45 \mathrm{~s}$ at $95^{\circ} \mathrm{C}, 45 \mathrm{~s}$ at $59^{\circ} \mathrm{C}$, and $1 \mathrm{~min}$ at $72^{\circ} \mathrm{C}$, followed by a final extension step of $5 \mathrm{~min}$ at $72^{\circ} \mathrm{C}$. For IGF-I they were: one cycle of $1 \mathrm{~min}$ at $95^{\circ} \mathrm{C}, 45 \mathrm{~s}$ at $59^{\circ} \mathrm{C}, 1 \mathrm{~min}$ at $72{ }^{\circ} \mathrm{C} ; 35$ cycles of $45 \mathrm{~s}$ at $95^{\circ} \mathrm{C}, 40 \mathrm{~s}$ at $60^{\circ} \mathrm{C}$, and $1 \mathrm{~min}$ at $72^{\circ} \mathrm{C}$, followed by a final extension step of $5 \mathrm{~min}$ at $72^{\circ} \mathrm{C}$. The PCR products were then analysed by electrophoresis on $1.5 \%$ agarose gels and purified using a PCR Purification Kit (Qiagen, Basel, Switzerland) according to the manufacturer's instructions. 
The rat insulin, IGF-I, glucagon and yeast $18 \mathrm{~S}$ ribosomal cDNA probes were labelled by random primer extension using a commercial kit (Boehringer Mannheim, Rotkreuz, Switzerland) and $\left[\alpha-{ }^{32} \mathrm{P}\right]$ deoxy-CTP $(3000 \mathrm{Ci} / \mathrm{mmol}$; Amersham, Cardiff, UK) to specific activities of $2-4 \times 10^{9}$ c.p.m./ $\mu \mathrm{g}$ DNA, following the manufacturer's instructions.

\section{Northern blotting}

Total RNA was isolated from pancreatic tissues using a commercial kit (see above). Twenty micrograms heat-denatured $\left(65^{\circ} \mathrm{C}, 15 \mathrm{~min}\right)$ RNA samples were electrophoresed on a $1 \%$ agarose gel containing $2 \mathrm{~mol} / \mathrm{l}$ formaldehyde, transferred to nylon membranes (Hybond-N, Amersham) by capillary blotting, and fixed by UV cross-linking. Membranes were prehybridized at $42{ }^{\circ} \mathrm{C}$ in a solution containing $50 \%(\mathrm{vol} / \mathrm{vol})$ deionized formamide, $5 \times$ Denhardt's solution $[0.02 \%(\mathrm{wt} / \mathrm{vol})$ Ficoll and $0.02 \%$ (wt/vol) polyvinyl pyrrolidone], $5 \times$ SSPE $(20 \times=3.6 \mathrm{~mol} / \mathrm{l} \mathrm{NaCl}, 0.2 \mathrm{~mol} / \mathrm{l}$ sodium phosphate, $0.02 \mathrm{~mol} / \mathrm{l}$ EDTA, pH 7.7), $0.2 \%$ SDS and $100 \mu \mathrm{g} / \mathrm{ml}$ heat-denatured salmon sperm DNA. Hybridizations were performed in the same solution with $\sim 2 \times 10^{7}$ c.p.m. labelled cDNA probe for insulin, IGF-I, glucagon and $18 \mathrm{~S}$ cDNA per membrane.

After $48 \mathrm{~h}$ of incubation at $42{ }^{\circ} \mathrm{C}$, the membranes were washed twice for $10 \mathrm{~min}$ at room temperature, and for $15 \mathrm{~min}$ at $54{ }^{\circ} \mathrm{C}$ (insulin, IGF-I), $51^{\circ} \mathrm{C}$ (glucagon) or $65^{\circ} \mathrm{C}(18 \mathrm{~S})$ in $0.1 \times \mathrm{SSC}-0.1 \%$ SDS. Membranes were then exposed at $-80{ }^{\circ} \mathrm{C}$ to an X-Omat AR-5 film (Kodak, Rochester, NY, USA) in cassettes equipped with intensifying screens to visualize $\left[{ }^{32} \mathrm{P}\right] \mathrm{CDNA}-\mathrm{mRNA}$ hybrids. Levels of mRNA were quantitated by scanning densitometry using a BioRad video densitometer (Richmond, CA, USA). Between consecutive hybridizations, the membranes were washed with $0.1 \times \mathrm{SSC}-0.1 \% \mathrm{SDS}$ at $98^{\circ} \mathrm{C}$ for $45 \mathrm{~min}$ to remove previous cDNA probe. Variations of gel loading were corrected against $18 \mathrm{~S}$ ribosomal RNA values.

\section{Statistical analysis}

All results are expressed as mean \pm S.E.M. Statistical analysis was performed by analysis of variance (significance level $<0.05$ ) with a StatView 4.5 program (Abacus Concepts, Inc., Berkeley, CA, USA).

\section{Results}

\section{Body weight and pancreatic weight}

GH and IGF-I treatment of the hypox rats resulted in a significant increase in body weight $(12.67 \pm 1.65 \mathrm{~g}$ and $7.50 \pm 1.18 \mathrm{~g}$ respectively) within 2 days, whereas vehicle-treated hypox rats lost $4.33 \pm 0.49 \mathrm{~g}$. Neither GH nor IGF-I caused significant changes in pancreas weight.

\section{Serum glucose}

The serum glucose concentration in hypox rats was $8.65 \pm 0.41 \mathrm{mmol} / \mathrm{l}$. GH treatment did not cause any change $(8.30 \pm 0.18 \mathrm{mmol} / \mathrm{l})$, whereas IGF-I treatment decreased serum glucose slightly, to $7.10 \pm 0.12 \mathrm{mmol} / \mathrm{l}$ $(P=0.001)$.

\section{Serum GH}

Serum concentrations of infused rhGH were $50.9 \pm 5.4 \mathrm{ng} / \mathrm{ml}$.

\section{Serum insulin and C-peptide concentrations, pancreatic insulin peptide and mRNA contents}

Serum insulin concentrations were significantly lower $(39 \pm 2 \mathrm{pmol} / \mathrm{l})$ in the IGF-I-treated group than in the vehicle-treated group $(162 \pm 25 \mathrm{pmol} / \mathrm{l}, \quad P=0.0001$; Fig. 1a). GH did not significantly affect serum insulin $(120 \pm 15 \mathrm{pmol} / \mathrm{l})$. The decrease in circulating insulin after IGF-I was accompanied by a drastic decrease in serum C-peptide, from $377 \pm 57 \mathrm{pmol} / \mathrm{l}$ to $39 \pm 7 \mathrm{pmol} / \mathrm{l}(P=0.0006$, Fig. 1b). Serum C-peptide remained unchanged after $\mathrm{GH}(355 \pm 77 \mathrm{pmol} / \mathrm{l})$. GH treatment increased the pancreatic insulin content from $176 \pm 28 \mu \mathrm{g} / \mathrm{g}$ to $241 \pm 18 \mu \mathrm{g} / \mathrm{g}$ pancreas $(+37 \%, P=0.009)$ and total insulin content per pancreas from $47.6 \pm 2.3 \mu \mathrm{g}$ to $63.4 \pm 4.5 \mu \mathrm{g}(+33 \%$, $P=0.018)$, whereas IGF-I did not affect the pancreatic insulin content $(188 \pm 15 \mu \mathrm{g} / \mathrm{g}$ pancreas; Fig. 1c) or the total insulin content per pancreas (57.2 $5.3 \mu \mathrm{g} /$ pancreas, $P=0.16)$. No significant changes in the pancreatic insulin mRNA levels were observed after GH or IGF-I treatment (Fig. 1d).

\section{Serum IGF-I, pancreatic IGF-I peptide and mRNA contents}

Serum IGF-I concentrations were significantly increased, from $161 \pm 15 \mathrm{ng} / \mathrm{ml}$ to $1889 \pm 128 \mathrm{ng} / \mathrm{ml}$ $(P<0.0001)$ by $\mathrm{GH}$ and to $586 \pm 42 \mathrm{ng} / \mathrm{ml}$ $(P=0.0017)$ by IGF-I treatment (Fig. 2a). Both GH and IGF-I also increased the IGF-I content of the pancreas, from $184 \pm 9 \mathrm{ng} / \mathrm{g}$ to $288 \pm 13 \mathrm{ng} / \mathrm{g}$ and $247 \pm 9 \mathrm{ng} / \mathrm{g}$ respectively $(P<0.0001$ and 0.0017 respectively; Fig. 2b). Each of these values was corrected for the IGF-I present in the blood serum retained in the pancreas $(24 \mu \mathrm{l} / \mathrm{g}$ pancreas). GH treatment resulted in a marked (83\%) increase in pancreatic IGF-I mRNA $(P<0.0001)$, whereas infused IGF-I did not affect pancreatic IGF-I gene expression (Fig. 2c).

\section{Serum glucagon, pancreatic glucagon peptide and mRNA contents}

GH treatment did not significantly change serum glucagon concentrations $(37.2 \pm 3.6 \mathrm{pmol} / \mathrm{l}$ as compared 

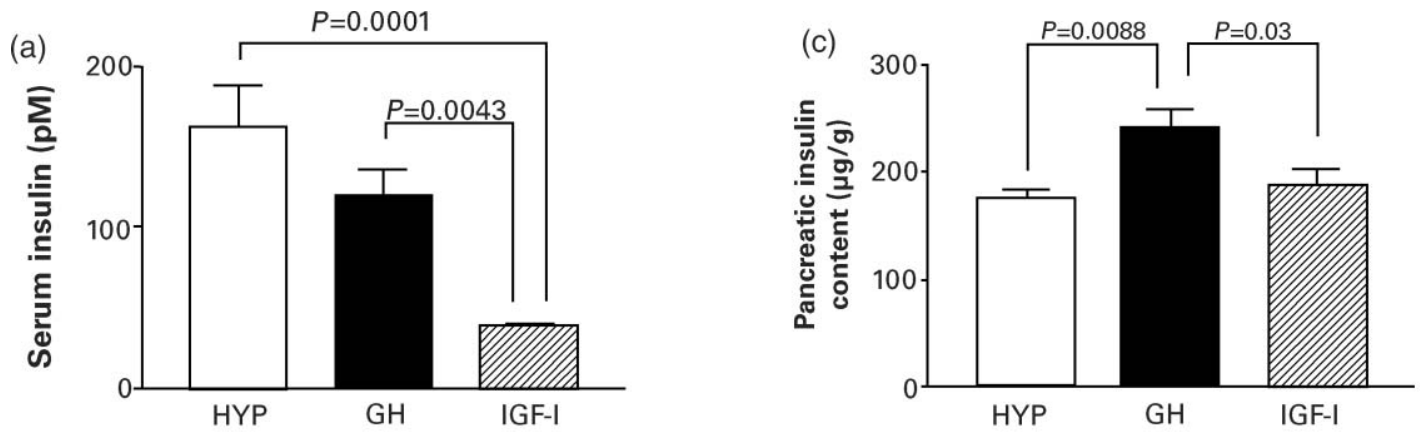

(b)

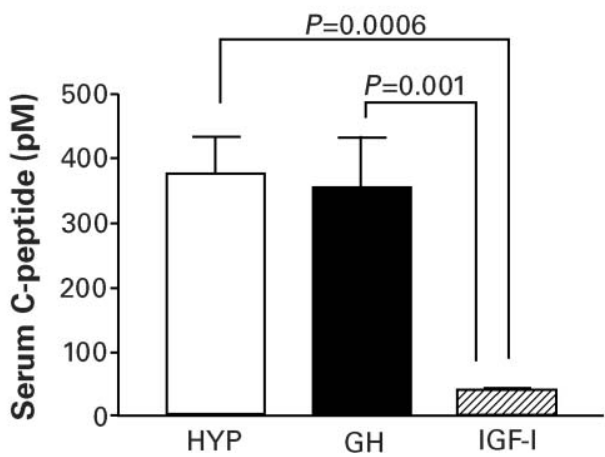

(d)
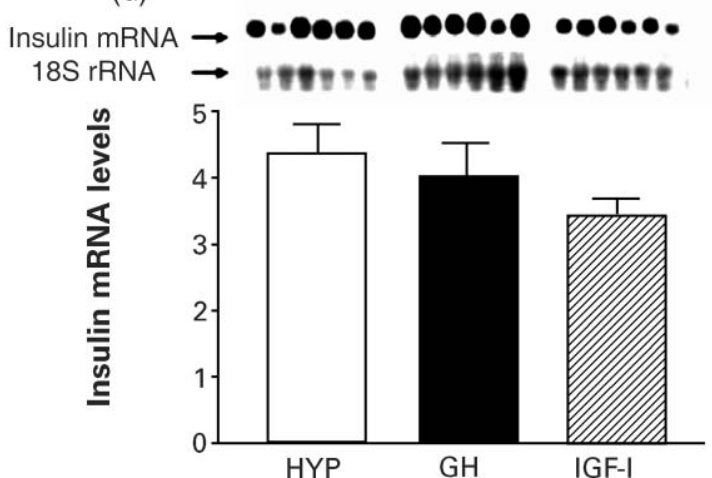

Figure 1 (a) Serum insulin, (b) C-peptide, (c) pancreatic insulin peptide content and (d) insulin mRNA levels of hypox controls (HYP), and $\mathrm{GH}$ - and rhlGF-I-treated hypox rats. Serum insulin, C-peptide and pancreatic insulin were measured by specific rat insulin and C-peptide RIAs; insulin mRNA was determined by northern analysis. Insulin mRNA and 18S rRNA signals are presented above the corresponding columns for each of the treatment groups. The insulin mRNA signals were normalized against the18S rRNA signals and expressed as relative levels. Columns give the mean values $(n=6)$ and bars give the S.E.M. Significance levels $(P)$ are indicated in $(a-c)$.

with $41.9 \pm 6.0 \mathrm{pmol} / \mathrm{l}$ in hypox controls), but IGF-I treatment caused a significant decrease, to $25.3 \pm 1.3 \mathrm{pmol} / \mathrm{l}(P=0.012$; Fig. 3a). GH significantly increased the pancreatic glucagon content, from $11.15 \pm 0.94 \mu \mathrm{g} / \mathrm{g}$ to $14.86 \pm 1.44 \mu \mathrm{g} / \mathrm{g}$ pancreas $(P=0.036)$, whereas the increase after IGF-I treatment was not statistically significant (Fig. 3b). Neither GH nor IGF-I caused significant changes in pancreatic glucagon mRNA (Fig. 3c).

\section{Immunofluorescence}

Insulin immunoreactivity in the $\beta$-cells was faint in islets from hypox and IGF-I-treated rats (Fig. 4a,c,d,f), but the staining intensity was markedly increased after GH treatment (Fig. 4b,e). Immunostaining for IGF-I, which appeared to be located in $\alpha$-cells as shown previously (11), was weak in hypox rats (Fig. 4a) and more intense in islets from GH-treated (Fig. 4b) but not from IGF-I treated rats (Fig. 4c). Similarly, glucagon immunoreactivity was more pronounced in the $\alpha$-cells of GH-treated rats (Fig. 4e) than in islets of hypox (Fig. 4d) or IGF-I-treated rats (Fig. 4f).

\section{Discussion}

The present study addressed the question whether endogenous IGF-I induced by GH replacement and exogenously replaced IGF-I elicit the same effect on the endocrine pancreas of the hypox rat. To this end, we investigated the serum concentrations of glucose, IGF-I, insulin, C-peptide and glucagon, and the expression of IGF-I, insulin and glucagon mRNAs and peptides, in pancreatic tissue after a 2-day infusion of GH and IGF-I respectively. The 2-day period of infusion was chosen on the basis of earlier experiments that had shown that maximal steady-state growth effects on the tibial growth plate were achieved after 2 days of GH or IGF-I treatment (12). As in our previous infusion studies in hypox rats $(9,12-14)$, no attempt was made to substitute thyroxine, cortisone or testosterone in our experimental animals.

GH treatment increased pancreatic IGF-I mRNA, as originally reported by Hynes et al. (15), whereas IGF-I infusion did not affect the expression of IGF-I mRNA. Both GH and IGF-I increased circulating and pancreatic IGF-I but, in contrast to GH, IGF-I substantially reduced serum insulin and C-peptide concentrations (-76\% and $-90 \%$ respectively), suggesting that it strongly 

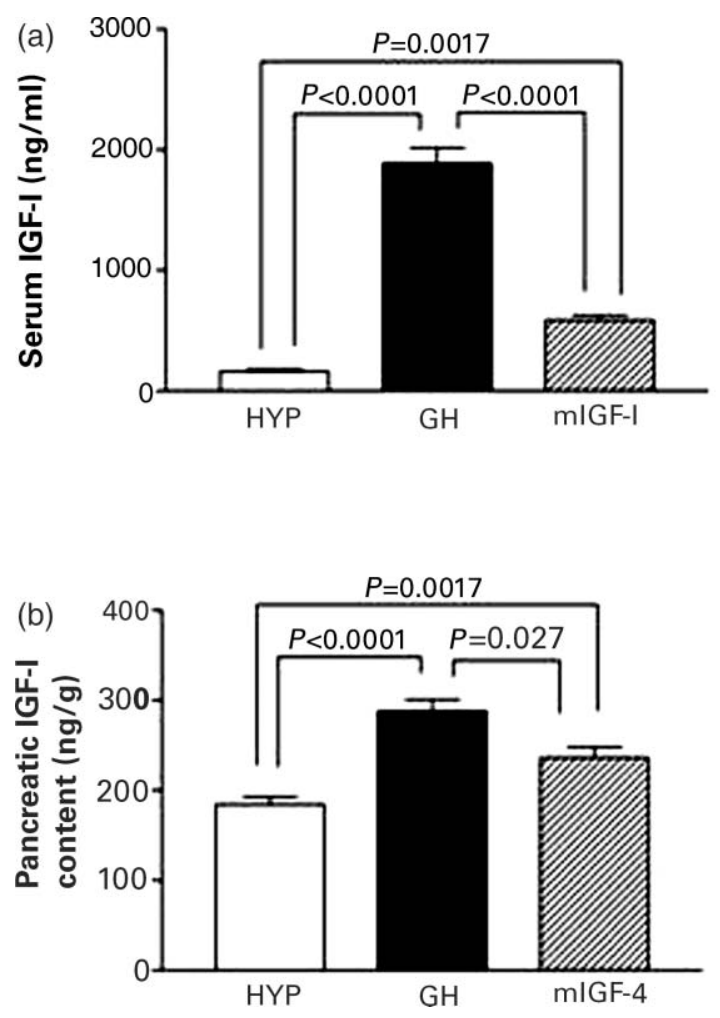

(c)

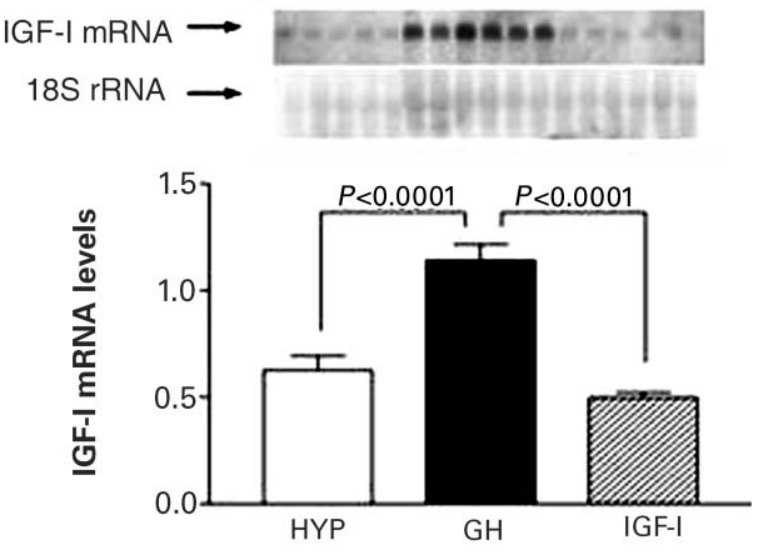

Figure 2 (a) Serum IGF-I, (b) pancreatic IGF peptide content and (c) IGF-I mRNA levels of hypox controls (HYP) and GH- and rhIGF-Itreated hypox rats. Serum IGF-I and pancreatic IGF-I were measured by two different RIAs, one for the detection of endogenous rat IGF-I in the GH-infused group and one for the detection of infused human IGF-I in the rhIGF-I-infused group (see Materials and methods); IGF-I mRNA was determined by northern analysis. IGF-I mRNA and 18S rRNA signals are shown above the corresponding columns for each of the treatment groups. IGF-I mRNA signals were normalized against the 18S rRNA signals and expressed as relative levels. Columns give the mean values $(n=6)$ and bars indicate S.E.M. Significance levels $(P)$ are shown.

inhibited insulin secretion. It is unlikely that decreased insulin concentrations were caused by enhanced insulin degradation, because the insulin/C-peptide ratio increased from 1:2.5 and 1:3 in control and in GH-treated animals respectively to 1:1 in the IGF-I-infused animals, suggesting that the insulin half-life in the latter was prolonged rather than decreased. This is also in line with reports that IGF-I inhibited insulin degradation in cultured human hepatoma cells (16) and in preparations of rat liver and rat kidney plasma membranes $(17,18)$. Furthermore, a $20-30 \%$ increase in glomerular filtration, which has been shown in IGF-I-treated rats (19), would hardly account for the dramatic decrease in serum insulin and C-peptide concentrations. We therefore interpret the latter to be the result of inhibition of insulin secretion, compatible with most reports in the literature (see below).

Insulin mRNA expression and pancreatic insulin content were not significantly changed by IGF-I treatment, as also confirmed by immunohistochemistry. However, these data do not allow conclusions to be drawn as to whether or not insulin biosynthesis at the transcriptional and translational levels was significantly affected by IGF-I treatment. As with insulin, the serum glucagon concentrations also were reduced by IGF-I, although less so $(-40 \%)$ than those of insulin, again without significant changes in pancreatic glucagon mRNA or peptide expression.

The findings obtained with GH showed essential differences from those observed with IGF-I infusion: although GH, like IGF-I, increased both circulating and pancreatic IGF-I, it did not affect serum glucose, insulin, C-peptide and glucagon, whereas it increased pancreatic insulin and glucagon content. These differences demonstrate that the effects of infused IGF-I in the absence of GH are not mimicked by endogenous circulating or pancreatic IGF-I induced by GH replacement. In contrast to these results in hypox rats, human studies in GH-deficient patients have shown that GH replacement increases serum insulin and glucose concentrations and reduces insulin sensitivity (5). The discrepancy between these and the findings in hypox rats may be attributable not only to species differences, but rather to the fact that $\mathrm{GH}$-deficient patients received other hormone replacement therapy in addition to GH.

Inhibition of insulin secretion by IGF-I has been shown both in vitro and in vivo. In the isolated perfused rat pancreas (20) and in purified rat $\beta$-cells (21), addition of IGF-I potently suppressed insulin secretion, suggesting a direct effect of IGF-I on the 
(a)
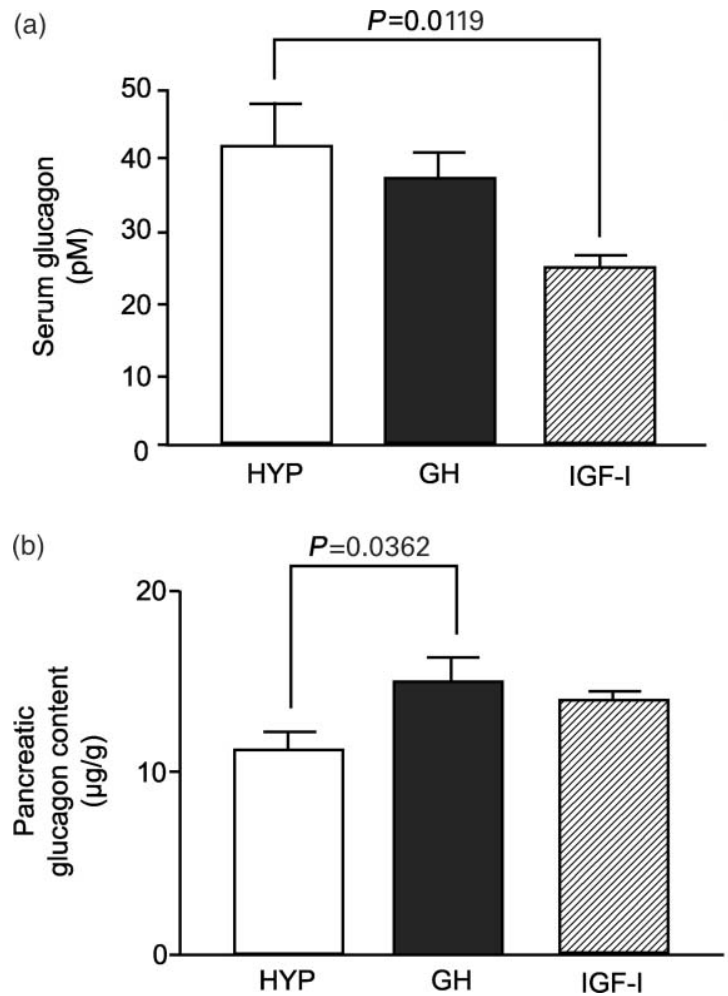

(c)
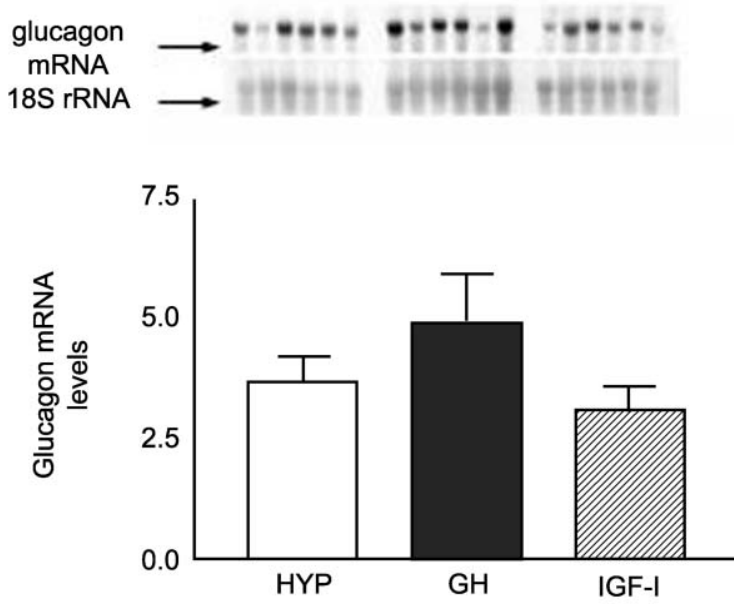

Figure 3 (a) Serum glucagon, (b) pancreatic glucagon content and (c) glucagon mRNA levels of hypox controls (HYP) and GH- and rhIGF-I- treated hypox rats. Serum and pancreatic glucagon were measured by a specific rat glucagon RIA; glucagon mRNA was determined by northern analysis. Northern blot signals for glucagon mRNA and 18S rRNA are shown above the corresponding columns for each of the treatment groups. Glucagon mRNA signals were normalized against 18S rRNA signals and expressed as relative levels. Columns give the mean values $(n=6)$ and bars represent S.E.M. Significance levels $(P)$ are shown.
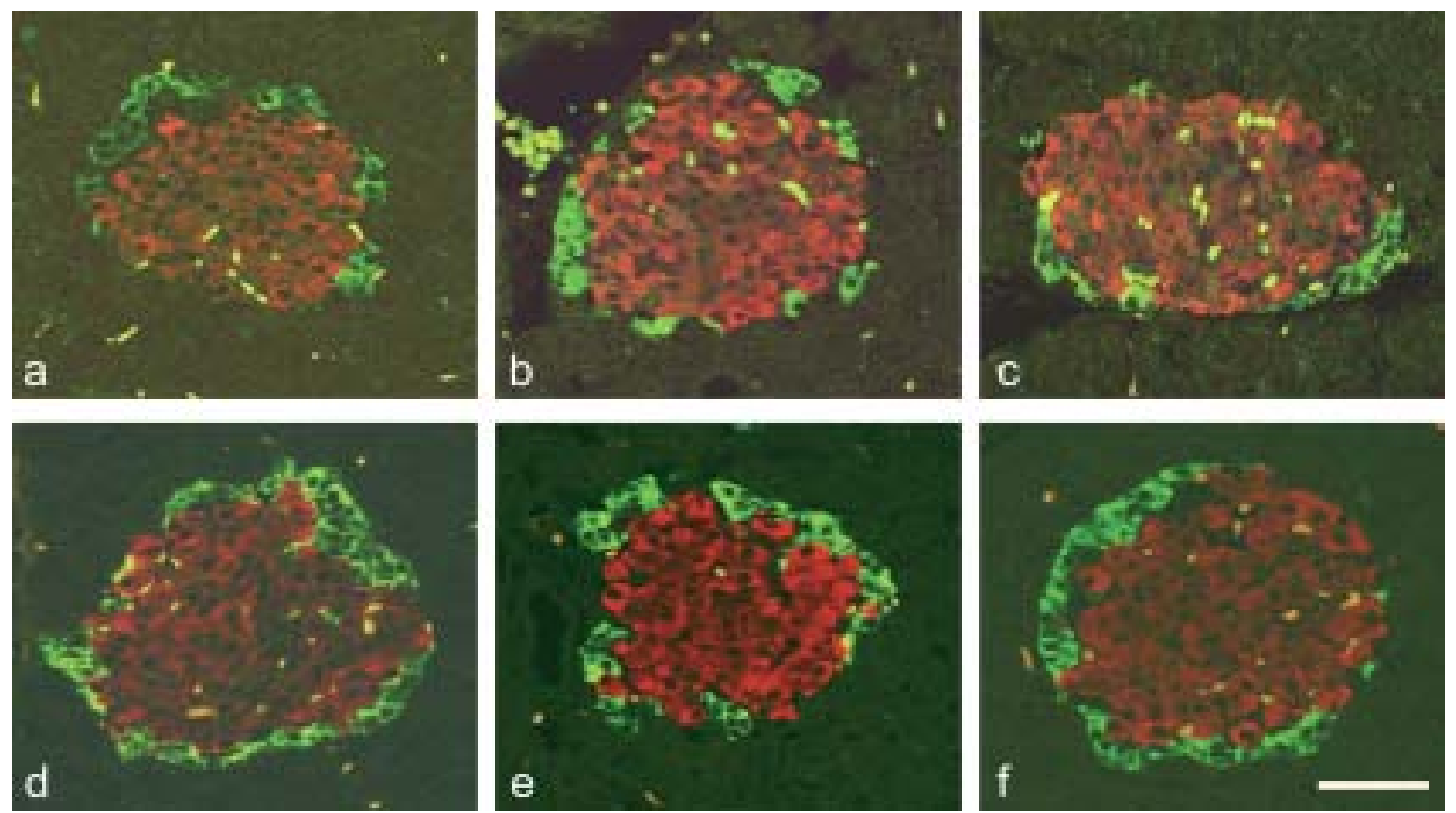

Figure 4 Localization of insulin (red fluorescence), IGF-I (a-c, green fluorescence) and glucagon (d-f, green fluorescence) revealed by double immunofluorescence in pancreatic islets from (a,d) hypox controls, (b,e) GH-treated and (c,f) IGF-I-treated hypox rats. In brief, pancreatic peptides were stained with primary antisera directed against insulin $(a-f)$ and IGF-I $(a-c)$ or glucagon (d-f), followed by fluorescence-coupled secondary antibodies. Microscopic images were obtained by confocal laser scanning. Bar represents $70 \mu \mathrm{m}$. 
$\beta$-cell. However, no inhibition of insulin release by IGF-I was observed in tissue cultures of human pancreatic islets (22), and both stimulation and inhibition of insulin release have been reported in isolated perifused rat islets, depending on the perifusion conditions (23). Inhibition of glucose-stimulated and glucagonlike peptide I-stimulated insulin secretion by IGF-I has been demonstrated in rat pancreatic monolayer cells and in the HIT-T15 $\beta$-cell line (24). Insulin secretion has also been found to be suppressed in humans infused with IGF-I $(5,25-27)$. A recent study in IGF-I-infused (6 days) hypox rats receiving L-thyroxine and cortisol substitution demonstrated that serum insulin and C-peptide concentrations were suppressed and that insulin sensitivity in isolated soleus muscle was enhanced (28), which is in line with results from studies in humans $(5,25-27)$. Our results in IGF-I-infused hypox rats are in agreement with these findings: despite largely reduced serum insulin concentrations, serum glucose did not increase, compatible with increased insulin sensitivity. Reduced serum glucagon concentrations in the IGF-Iinfused animals may also have contributed to balancing glucose homeostasis. However, it cannot be excluded that IGF-I exerted additional insulin-like effects. Thus we had found previously that hypox rats infused with IGF-I became hypoglycaemic during the first $8 \mathrm{~h}$ of the infusion (29). Blood sugar concentrations increased after $16 \mathrm{~h}$, together with the induction of IGF binding protein (IGFBP)-3 (29), and were not different from those of hypox controls when the infusion lasted for 6 days or longer $(9,12,13,28)$.

The mechanism whereby IGF-I inhibits insulin secretion has been investigated by Zhao et al. (24) in cultures of neonatal rat pancreatic monolayer cells and in the HIT-T15 $\beta$-cell line. These authors demonstrated that IGF-I activates phosphodiesterase 3B (PDE $3 \mathrm{~B})$ in the $\beta$-cells, thereby decreasing the intracellular cyclic AMP concentration and thus inhibiting insulin secretion. On the basis of these in vitro findings, an interesting in vivo feedback model was postulated in which 'IGF-I inhibition of insulin secretion through activation of PDE $3 \mathrm{~B}$ may constitute part of a major homeostatic control mechanism for regulation of insulin secretion' (24). In this model, increased insulin secretion would stimulate IGF-I synthesis and release by the liver, resulting in increased circulating IGF-I, interaction of the latter with the IGF-I receptors on the $\beta$-cell, activation of PDE 3B, a decrease in intracellular cyclic AMP and, finally, in attenuation of insulin release. Although part of this model is consistent with our findings in IGF-I-infused hypox rats, it is at variance with our results in the GH-infused animals. Here, stimulation of endogenous circulating or pancreatic IGF-I did not inhibit insulin secretion. In vivo, both circulating and tissue IGF-I are essentially under the control of $\mathrm{GH}$, and increased endogenous IGF-I always occurs in association with increased $\mathrm{GH}$ secretion - a situation similar to that in our GH-infused hypox rats. It is, therefore, difficult to distinguish between the potential effects of endogenous IGF-I and the potential direct, IGF-I-independent effects of GH. Furthermore, the question as to what extent endogenous IGF-I reaches the $\beta$-cell to interact with IGF-I receptors remains unresolved. As in normal rats, IGF-I in GH-treated hypox rats circulates predominantly as a $150 \mathrm{kDa}$ ternary complex (29), together with IGFBP-3 and an acid-labile subunit (30). The capillary permeability of this complex, and thus the bioavailibity of the IGF-I bound to it, seem to be largely restricted (31). This is different in IGF-I-infused hypox rats. Here, the $150 \mathrm{kDa}$ complex is lacking (32) and the infused IGF-I circulates in association with the smaller, 40-50 kDa, binding protein complex, which can pass the capillary bed and deliver the infused IGF-I to IGF-I receptors (32). Thus a quantitative comparison of the circulating IGF-I concentrations in the two infusion conditions does not appear to be straightforward. It was therefore important to determine pancreatic (local) IGF-I concentrations in GH- and IGF-I-infused animals, which may more adequately reflect conditions at the tissue level. We found that both GH and IGF-I treatment increased IGF-I in the pancreatic tissue, GH even more than infused IGF-I.

Nevertheless, two questions remain unanswered. Firstly, why does the GH-induced increase in endogenous pancreatic IGF-I not affect insulin secretion in the same way as the increase in pancreatic IGF-I caused by rhIGF-I infusion? Pancreatic IGF binding proteins (as determined by western ligand blotting of pancreatic extracts), which could be responsible for the discrepancy in insulin secretion discussed above, were nearly undetectable in the treated animals after 9 days of exposure of the membrane to the X-ray film (not shown). Therefore, one possible explanation may be that $\mathrm{GH}$ counteracts locally produced IGF-I in the pancreas by a direct, IGF-I-independent mechanism. Another explanation would be that the actions of infused IGF-I on muscle and of GH on liver, fat and muscle metabolism result in opposite effects on glucose availability. These effects probably contribute to insulin needs and thus to the observed differences in serum insulin concentrations between our IGF-I- and GH-treated animals. The second question is why GH replacement and IGF-I infusion act in concert on skeletal growth of hypox rats, whereas they do not with respect to insulin secretion. To date, IGF research has not offered any explanation for these apparently puzzling inconsistencies.

In summary, our results show that infused IGF-I in the absence of $\mathrm{GH}$ does not affect pancreatic insulin mRNA and peptide expression, but strongly reduces serum insulin concentrations, which suggests that it inhibits insulin secretion and enhances insulin sensitivity. Endogenous GH-induced circulating or pancreatic IGF-I does not act on the endocrine pancreas in analogy to administered IGF-I. 


\section{Acknowledgements}

We thank Mrs Gunthild Krey and Mrs Cornelia Zwimpfer for skilful technical assistance. The work was supported by grants nos 32-46808.96 and 32.61481.00 of the Swiss National Science Foundation, and by the Hartmann-Müller Stiftung für Medizinische Forschung of the University of Zürich.

\section{References}

1 D'Ercole AJ, Applewhite GT \& Underwood LE. Evidence that somatomedin is synthesized by multiple tissues in the fetus. Developmental Biology $198075315-328$.

2 D'Ercole AJ, Stiles AD \& Underwood LE. Tissue concentrations of somatomedin C: further evidence for multiple sites of synthesis and paracrine or autocrine mechanisms of action. PNAS 1984 81 935-939.

3 D'Ercole AJ \& Calikoglu AS. Editorial review: the case of local versus endocrine IGF-I actions: the jury is still out. Growth Hormone and IGF Research $200111261-265$.

4 Butler AA \& LeRoith D. Minireview: tissue-specific versus generalized gene targeting of the igf1 and igflr genes and their roles in insulin-like growth factor physiology. Endocrinology $2001 \mathbf{1 4 2}$ 1685-1688.

5 Hussain MA, Schmitz O, Mengel A, Glatz Y, Christiansen JS, Zapf J \& Froesch ER. Comparison of the effects of growth hormone and insulin-like growth factor I on substrate oxidation and on insulin sensitivity in growth hormone-deficient humans. Journal of Clinical Investigation $1994941126-1133$.

6 Yakar S, Liu JL, Fernandez AM, Wu Y, Schally AV, Frystyk J, Chernausek SD, Mejia W \& Le Roith D. Liver-specific igf-1 gene deletion leads to muscle insulin insensitivity. Diabetes 200150 $1110-1118$

7 Sjogren K, Wallenius K, Liu JL, Bohlooly YM, Pacini G, Svensson L, Tornell J, Isaksson OG, Ahren B, Jansson JO \& Ohlsson C. Liverderived IGF-I is of importance for normal carbohydrate and lipid metabolism. Diabetes 200150 1539-1545.

8 Boni-Schnetzler M, Hauri C \& Zapf J. Leptin is suppressed during infusion of recombinant human insulin-like growth factor I (rhIGF-I) in normal rats. Diabetologia 199942 160-166.

9 Zapf J, Gosteli-Peter M, Weckbecker G, Hunziker EB \& Reinecke M. The somatostatin analog octreotide inhibits GH-stimulated, but not IGF-I-stimulated, bone growth in hypophysectomized rats. Endocrinology $20021432944-2952$.

10 Hohorst HJ, Kreutz FH \& Bücher T. Ueber Metabolitgehalte und Metabolit-Konzentrationen in der Leber in der Ratte. Biochemische Zeitschrift $195033218-46$.

11 Maake C \& Reinecke M. Immunohistochemical localization of insulin-like growth factor 1 and 2 in the endocrine pancreas of rat, dog, and man, and their coexistence with classical islet hormones. Cell Tissue Research 1993273 249-259.

12 Hunziker EB, Wagner J \& Zapf J. Differential effects of insulin-like growth factor I and growth hormone on developmental stages of rat growth plate chondrocytes in vivo. Journal of Clinical Investigation $1994931078-1086$.

13 Guler HP, Zapf J, Scheiwiller E \& Froesch ER. Recombinant human insulin-like growth factor I stimulates growth and has distinct effects on organ size in hypophysectomized rats. PNAS $1988 \mathbf{8 5}$ 4889-4893.

14 Reinecke M, Schmid AC, Heyberger-Meyer B, Hunziker EB \& Zapf J. Effect of growth hormone and insulin-like growth factor I (IGF-I) on the expression of IGF-I messenger ribonucleic acid and peptide in rat tibial growth plate and articular chondrocytes in vivo. Endocrinology $2000 \mathbf{1 4 1} 2847-2853$.

15 Hynes MA, Van Wyk JJ, Brooks PJ, D’Ercole AJ, Jansen M \& Lund PK. Growth hormone dependence of somatomedin-C/insulin-like growth factor-I and insulin-like growth factor-II messenger ribonucleic acids. Molecular Endocrinology $19871233-242$.

16 Keller S, Schmid C, Zapf J \& Froesch ER. Inhibition of insulin degradation by insulin-like growth factors I and II in human hepatoma (HepG2) cells. Acta Endocrinologica $1989 \quad 121$ 279-285.

17 Kahn CR, Megyesi K \& Roth J. Nonsuppressible insulin-like activity of human serum. A potent inhibitor of insulin degradation. Journal of Clinical Investigation 1976 57 526-529.

18 D'Ercole AJ, Decedue CJ, Furlanetto RW, Underwood LE \& Van Wyk JJ. Evidence that somatomedin-C is degraded by the kidney and inhibits insulin degradation. Endocrinology 1977 $101577-586$.

19 Hirschberg R \& Kopple JD. Evidence that insulin-like growth factor I increases renal plasma flow and glomerular filtration in fasted rats. Journal of Clinical Investigation 198983 326-330.

20 Leahy JL \& Vandekerkhove KM. Insulin-like growth factor-I at physiological concentrations is a potent inhibitor of insulin secretion. Endocrinology 1990126 1593-1598.

21 Van Schravendijk CF, Heylen L, Van den Brande JL \& Pipeleers DG. Direct effect of insulin and insulin-like growth factor-I on the secretory activity of rat pancreatic beta cells. Diabetologia 1990 $33649-653$.

22 Eizirik DL, Skottner A \& Hellerstrom C. Insulin-like growth factor I does not inhibit insulin secretion in adult human pancreatic islets in tissue culture. European Journal of Endocrinology 1995133 $248-250$.

23 Hill DJ, Sedran RJ, Brenner SL \& McDonald TJ. IGF-I has a dual effect on insulin release from isolated, perifused adult rat islets of Langerhans. Journal of Endocrinology 1997153 15-25.

24 Zhao AZ, Zhao H, Teague J, Fujimoto W \& Beavo JA. Attenuation of insulin secretion by insulin-like growth factor 1 is mediated through activation of phosphodiesterase 3B. PNAS $1997 \mathbf{9 4}$ 3223-3228.

25 Guler HP, Zapf J \& Froesch ER. Short-term metabolic effects of recombinant human insulin-like growth factor I in healthy adults. New England Journal of Medicine 1987317 137-140.

26 Hussain MA, Schmitz O, Mengel A, Keller A, Christiansen JS, Zapf J \& Froesch ER. Insulin-like growth factor I stimulates lipid oxidation, reduces protein oxidation, and enhances insulin sensitivity in humans. Journal of Clinical Investigation 199392 2249-2256.

27 Zenobi PD, Graf S, Ursprung H \& Froesch ER. Effects of insulin-like growth factor-I on glucose tolerance, insulin levels, and insulin secretion. Journal of Clinical Investigation $1992891908-1913$.

28 Frick F, Oscarsson J, Vikman-Adolfsson K, Ottosson M, Yoshida N \& Eden S. Different effects of IGF-I on insulin-stimulated glucose uptake in adipose tissue and skeletal muscle. American Journal of Physiology Endocrinology and Metabolism 2000278 E729-E737.

29 Zapf J, Hauri C, Waldvogel M, Futo E, Hasler H, Binz K, Guler HP, Schmid C \& Froesch ER. Recombinant human insulin-like growth factor I induces its own specific carrier protein in hypophysectomized and diabetic rats. PNAS 198986 3813-3817.

30 Baxter RC \& Martin JL. Structure of the Mr 140,000 growth hormone-dependent insulin-like growth factor binding protein complex: determination by reconstitution and affinity-labeling. PNAS $1989866898-6902$.

31 Binoux M \& Hossenlopp P. Insulin-like growth factor (IGF) and IGF-binding proteins: comparison of human serum and lymph. Journal of Clinical Endocrinology and Metabolism $1988 \quad \mathbf{6 7}$ 509-514.

32 Zapf J, Hauri C, Futo E, Hussain M, Rutishauser J, Maack CA \& Froesch ER. Intravenously injected insulin-like growth factor (IGF) I/IGF binding protein-3 complex exerts insulin-like effects in hypophysectomized, but not in normal rats. Journal of Clinical Investigation 199595 179-186.

Received 15 January 2004

Accepted 20 April 2004 